\title{
Is Preventing Heart Disease Causing Type 2 Diabetes
}

\author{
Satpal Singh Shekhawat* \\ Kirton Lindsey Surgery, United Kingdom
}

Submission: August 21, 2017; Published: August 29, 2017

*Corresponding author: Satpal Singh Shekhawat, Kirton Lindsey Surgery, Traingate, Kirton Lindsey, United Kingdom, DN21 4PQ

Tel: 784-960-5933; Email: satpal.shekhawat@nhs.net

\begin{abstract}
This article is an opinion on a plausible link between dietary advice to prevent heart disease and increased incidence of type 2 diabetes. In last three decades we have seen an increase in type 2 diabetes which coincides with promotion of more carbohydrate consumption and low fat diet to prevent heart disease. Health professionals around the world have been advising patients to eat less fatty food and increase carbohydrate consumption to avoid heart disease. Carbohydrates in the diet are easily turned to glucose thus creating hyperglycaemic states and leading towards increased incidence of type 2 diabetes in all populations. South East Asians who are prone to increased heart disease (1.5 times more risk than a Caucasians) after following this dietary advice are more likely to become Type 2 diabetic due to genetic predisposition and increased carbohydrate intake. Sugar (carbohydrates) is the new smoking and by promoting carbohydrates over fats we have led to increased carbohydrate intake which has consequently, led to insulin resistance and type 2 diabetes, even more so in susceptible individuals like South East Asians. Global figures of disease incidence and prevalence confirm this trend of rising type 2 diabetes and make my opinion stronger.
\end{abstract}

Keywords: Carbohydrate; Diabetes; Dietary advice; Heart disease; South east asians

\section{Opinion}

Heart disease has been one of the major causes of deaths in our population for many decades. In late 20th century as heart disease was on the rise, health professionals started advising patients on lifestyle choices to prevent heart disease. Apart from exercise, weight loss and stopping smoking, emphasis was laid on diet as well. General advice on prevention of heart disease included plenty of fruit and vegetables, meat, fish, low-fat and salt intake and use of starchy foods such as bread, rice, potatoes and pasta. Cardiovascular disease was responsible for $27 \%$ of all deaths in the UK in 2014 [1]. This figure demonstrates the vast number of people who are affected by cardiovascular disease and then receive advice on cardio protective diet for primary or secondary prevention [2]. This advice included reducing total fat intake to be $30 \%$ or less of total daily intake and saturated fat should be less than $7 \%$. It also emphasised use of whole grain varieties of cereals, bread and other starchy food.

Patients were faced with a challenge to reduce their fat intake in order to prevent or manage their cardiovascular disease and thus replaced the calories with carbohydrates. Carbohydrate is a nutrient which can have the greatest effect in raising bloodglucose levels in our body, which afterwards requires insulin for its suitable processing. If a person has constant hyperglycaemia which is not managed by appropriate insulin secretion, then it would lead to insulin resistance, pre diabetes or Type 2 diabetes. It is well known that dietary carbohydrates can influence the development of type 2 diabetes [3].

We also know that low-carbohydrate diet forum has been cited as a leading resource in providing support and encouragement for people that are wanting to achieve lower HbA1c levels and sustain effective weight loss [4]. As human beings, we all need to eat to provide energy to run essential body functions, and we all have three main groups of food to eat i.e. carbohydrates, protein and fat. Historically, cave men ate more protein and animal fat compared to carbohydrates and led a very physically active life. All that has since changed and we are now growing food and eating more refined products, which easily provide energy and indirectly raise blood sugars. Industrial revolution and modernization have brought comforts and reduced need for physical activity thus causing imbalance in our intake and burning of calories. This has led to obesity and lifestyle-related illness like the type 2 diabetes to increase.

If we as health professionals are delivering lifestyle advice to patients which is flawed it can result in undesired consequences, like increased starchy foods to reduce fat content in diet leading to hyperglycaemia and type 2 diabetes. Patients are confused as they don't know what advice to follow due to varied dietary 
advice given by different specialists and social media adding to this increased confusion. A great physicist had proved that 'for every action, there is an equal opposite reaction' (Newton) and that is what we are facing here in my opinion, although I accept we are not talking about laws of motion here and this is not directly transferable, but I feel there is a conceptual overlap which does exist. We have changed our eating patterns, physical activity has reduced and that is leading to lots of chronic diseases which are avoidable.

So what is the solution for this problem? In my opinion we need to move away from the concept of one diet fits all and work towards individual centered nutritional advice. That would take into account ethnicity, family history, activity levels, existing morbidities and medication and then provide diet and exercise advice, which is doable for the individual. If we as health professionals are able to provide bespoke lifestyle advice encompassing diet and exercise guidance, we can certainly cause a change to our patient's health and contribute towards disease prevention. In this environment of the global rise in chronic long term condition's emphasis on such service is required and of course training for health professionals needs to be developed.

\section{References}

1. BHF (2015) Cardiovascular disease statistics. British Heart Foundation.

2. NICE (2013) MI-secondary prevention. Secondary prevention in primary and secondary care for patients following a myocardial infarction (NICE guideline). Clinical guideline 172 National Institute for Health and Care Excellence: Clinical Guidelines.

3. Gross LS, Li L, Ford ES, Liu S (2004) Increased consumption of refined carbohydrates and the epidemic of type 2 diabetes in the United States: an ecologic assessment. Am J Clin Nutr 79(5): 774-779.

4. Unwin D, Unwin J (2014) Low carbohydrate diet to achieve weight loss and improve HbA1c in type 2 diabetes and pre diabetes: experience from one general practice. Practical Diabetes 31(2): 76-79.

\begin{tabular}{|l|}
\hline \multicolumn{1}{|c|}{ Your next submission with Juniper Publishers } \\
will reach you the below assets \\
- Quality Editorial service \\
- Swift Peer Review \\
- Reprints availability \\
- E-prints Service \\
- Manuscript Podcast for convenient understanding \\
- Global attainment for your research \\
- Manuscript accessibility in different formats \\
( Pdf, E-pub, Full Text, Audio) \\
- Unceasing customer service \\
Track the below URL for one-step submission \\
https://juniperpublishers.com/online-submission.php \\
\hline
\end{tabular}

